\title{
ANDREA MARIANI, LE SPERANZE E LA SPERANZA CRISTIANA. PER UN AGIRE ETICO TRA IL , GIÀ” E IL ,NON ANCORA”, BOLOGNA 2009, SS. 220
}

W świecie rzeczy nadzieja spełnia niezwykle ważną rolę, gdyż to ona nadaje wszystkiemu właściwy sens i kierunek. A choć łączy się ze światem rzeczy, to jednak najważniejszą rolę spełnia w życiu samego człowieka. Nadzieja jest jednym z najważniejszych wymiarów ludzkiego pielgrzymowania. Takiemu przekonaniu daje wyraz publikacja ks. prof. Andrei Marianiego (ur. 1967, wykładowca na rzymskim Ateneo Regina Apostolorum, a także na Diecezjalnym Instytucie Teologicznym w Tortonie), który podkreśla, że to, czego brakuje dzisiaj, to nie rzeczy, ale ich sens. Wyrusza więc na poszukiwanie sensu rzeczy, a za „przewodnika” obiera sobie encyklikę o nadziei Spe salvi (2007) papieża Benedykta XVI. Nie jest to jednak komentarz do dokumentu Papieża, ale pogłębiona analiza jednego z istotnych wymiarów nadziei, jakim jest jej wymiar etyczny. Zdaniem Autora kontekst społeczny i kulturalny, który przyczynił się do rozbudowania teologii nadziei, zmienił się zasadniczo na niekorzyść samej nadziei, która ustąpiła miejsca „zasadzie odpowiedzialności” [Hans Jonas (1903-1993)]. Czy jednak możliwa jest jakakolwiek odpowiedzialność bez nadziei, a tym bardziej w odniesieniu do przyszłości? - pyta i zarazem odpowiada Mariani. Jeśli zaczyna brakować nadziei, również odpowiedzialność popada w stan rezygnacji i rozpaczy wobec zła obecnego w świecie i niemożliwości jego pokonania. Jedyną pewną nadzieją człowieka nie jest rzecz, ale Osoba - Jezus Chrystus. W świecie współczesnym, który jest niezwykle ubogi w nadzieję, a samo oczekiwanie i przyszłość staje się coraz bardziej oderwane od człowieka, ten sam człowiek tylko w Chrystusie i dzięki Niemu może osiągnąć swą pełnię.

W samym centrum teologicznych rozważań Marianiego o nadziei znajduje się Osoba Jezusa Chrystusa, a zwłaszcza tajemnica Jego Zmartwychwstania. W ten sposób problematyka nadziei łączy się z problematyką wiary, a sama nadzieja chrześcijańska łączy się z wiarą w Zmartwychwstałego. Sięgając do Biblii, Mariani wskazuje na trzy węzły tematyczne, które ukazują perspektywę nadziei chrześcijańskiej. W pierwszej kolejności jest to horyzont eschatologiczno-apokaliptyczny nadziei (List do Efezjan, Pierwszy List do Tesaloniczan, List do Rzymian). Słowo Boże, które przyjmuje człowiek, domaga się, aby było Ono słowem jego życia. Chodzi tu o życie w Chrystusie oraz z Chrystusem, które zawiera w sobie w sposób naturalny wymiar moralny. Wymiar ten wyraża się w ukierunkowaniu na dar z siebie w miłości. Najdoskonalszym wyrazem takiej miłości jest śmierć Pana Jezusa na krzyżu. W Chrystusie objawiło się całe misterium miłości Boga do człowieka i świata. Stąd Chrystus jest dla chrześcijanina najgłębszym motywem nadziei. Przedłużeniem 
wymiaru moralnego nadziei chrześcijańskiej jest jej wymiar świadectwa. Tu Mariani mówi o Chrystusie jako najdoskonalszym wzorze świadectwa, a następnie o świadectwie chrześcijanina pozostającego w bliskim związku z Chrystusem, a także wskazuje na konieczność wzrastania w nadziei, gdyż człowiek nadziei, to człowiek, który nieustannie szuka Chrystusa zmartwychwstałego, przez którego został już „znaleziony”. Jest to proces ciągłej przemiany (metanoia), który staje się aktem poznania-posłuszeństwa.

Oprócz wyraźnie podkreślonego wymiaru antropologicznego i chrystologicznego nadziei na uwagę zasługuje także uwypuklenie przez Marianiego całej dynamiki duszpasterskiej, która staje się swoistą pedagogią nadziei. Ukierunkowanie pracy duszpasterskiej na rzeczywistość przyszłą (w znaczeniu ,jeszcze nie”) obejmuje tak ożywienie ducha modlitwy, jak i swoistą edukację wobec rzeczywistości najtrudniejszej, jaką jest cierpienie i śmierć. Potrzebę pedagogii - edukacji na rzecz nadziei uznać należy dziś za szczególną potrzebę czasu. Winna ona dokonywać się począwszy od najmniejszej komórki życia społecznego, jaką jest rodzina. Wobec niepokojów obecnych w człowieku i w świecie Mariani podkreśla także radość, jaką niesie ze sobą nadzieja. Jest to radość świętości, która pozwala człowiekowi cieszyć się bliskością Boga. Kościół, którego jednym z przymiotów jest świętość, jest $\mathrm{w}$ świecie szczególnie uprzywilejowanym głosicielem nadziei.

$\mathrm{W}$ ostatecznym rozrachunku, jak konkluduje Autor, człowiek wierzący to człowiek nadziei. Wiele nadziei typowo ludzkich związanych ze środowiskiem i sposobem życia człowieka nie może przysłonić mu, a tym bardziej wyeliminować najważniejszej nadziei, nadziei w pełni chrześcijańskiej, która swe źródło i centrum znajduje w Chrystusie. I choć nadzieja chrześcijańska nie eliminuje ani trudności, ani ograniczeń ludzkich, to jednak nadaje wszystkiemu właściwy sens. 